\title{
ANTIHYPERTENSIVE DRUG UTILISATION PATTERN AMONG CHRONIC KIDNEY DISEASE PATIENTS UNDERGOING MAINTENANCE DIALYSIS IN A TERTIARY CARE TEACHING HOSPITAL
}

\author{
${ }_{1}^{1}$ Post Graduate Trainee, Department of Pharmacology, SCBMCH, Cuttack. \\ ${ }^{2}$ Assistant Professor, Department of Pharmacology, SCBMCH, Cuttack. \\ ${ }^{3}$ Post Graduate Trainee, Department of Pharmacology, SCBMCH, Cuttack. \\ ${ }^{4}$ Associate Professor, Department of Medicine, SCBMCH, Cuttack. \\ 5 Professor and HOD, Department of Pharmacology, SCBMCH, Cuttack.
}

P. Ansuman Abhisek ${ }^{1}$, Rajendra Pandaㄹ, Jigyansa Mohapatra ${ }^{3}$, Namita Mohapatra ${ }^{4}$, Srikanta Mohanty 5

ABSTRACT
BACKGROUND
The world is facing a global epidemic of Chronic Kidney Disease (CKD), a major threat to health in general because of an
increasing incidence, high cost of treatment and poor outcome associated with various adverse events and comorbidities. Although
improved control of hypertension is known to attenuate progression of Chronic Kidney Disease (CKD), a little is known about the
adequacy of treatment of hypertension in patients with CKD in India.

AIM

To analyse the utilisation pattern of anti-hypertensive agents in patients with Chronic Kidney Disease in a tertiary care teaching Hospital.

\section{MATERIAL AND METHODS}

A descriptive prospective study was conducted in the Department of Nephrology, S. C. B. Medical College and Hospital,

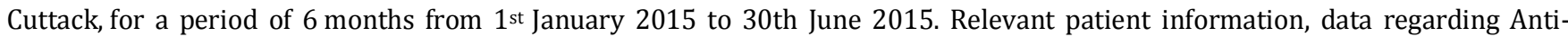
Hypertensive Drugs Utilization pattern entered in a preformed proforma in Microsoft Excel sheet for compilation and subjected to statistical analysis.

\section{RESULTS}

Total 100 case records were analysed. Mean age was $55.37 \pm 13.41$ years. Male-female ratio was 2.7. Maximum number of patients were from age group 51-60 years (43\%) followed by age group 41-50 years (29\%). All the patients (100\%) were hypertensives, among which $42 \%$ patients of the study population were diabetic with hypertension and rest of the patients (58\%) were non-diabetic with hypertension. Routinely prescribed anti-hypertensives are CCB, $\beta$ blockers, diuretics, $\alpha$ blockers, ACEI and centrally acting sympatholytics. Among them, Calcium Channel Blockers (32.47\%) were most frequently used followed by $\beta$ Blockers (24.78\%), Diuretics (23.50\%), Centrally Acting Sympatholytics (10.25\%), $\alpha$ Blockers (7.69\%) and ACE Inhibitors (1.28\%). Hypertension in CKD patients was very difficult to manage. Approximately, two-third of the patients (66\%) had BP >140/90 mmHg with anti-hypertensive therapy. Targeted blood pressure control was present in (34\%) of the patients.

\section{CONCLUSION}

Control of hypertension is poor in participants with CKD and that lack of control is primarily Systolic Hypertension. So a permutation and combination of various anti-hypertensive agents were used in CKD patients undergoing maintenance dialysis.

\section{KEYWORDS}

Chronic Kidney Disease, Hypertension, Anti-Hypertensive Drugs, Blood Pressure.

HOW TO CITE THIS ARTICLE: Abhisek PA, Panda R, Mohapatra J, et al. Antihypertensive drug utilisation pattern among chronic kidney disease patients undergoing maintenance dialysis in a tertiary care teaching hospital. J. Evolution Med. Dent. Sci. 2016;5(50):3207-3211, DOI: 10.14260/jemds/2016/744

\section{INTRODUCTION}

Drug utilisation study is defined as "the marketing, distribution, prescription and utilization of drugs in the society with special emphasis on the resulting medical, social and economic consequences" and has the main aim of facilitating the rational use of drugs, which is very important in decision making for healthcare.[1]

Financial or Other, Competing Interest: None.

Submission 05-05-2016, Peer Review 30-05-2016,

Acceptance 06-06-2016, Published 23-06-2016.

Corresponding Author:

Dr. P. Ansuman Abhisek,

Plot No. 23,

Jaya Durga Nagar,

Cuttack Road,

Bhubaneswar-751006, Odisha.

E-mail: ansumanabhisek123@gmail.com

DOI: $10.14260 /$ jemds $/ 2016 / 744$
Chronic Kidney Disease (CKD) is a worldwide health problem with adverse events, Cardiovascular Disease (CVD) and premature death.[2] CKD is characterized by progressive loss of renal mass with irreversible sclerosis and loss of nephrons over a period of months to years, which depends on the underlying aetiology. ${ }^{[3]}$ Hypertension doubles the risk of cardiovascular diseases including Coronary Heart Disease (CHD), congestive heart failure, ischaemic and haemorrhagic stroke, renal failure and peripheral arterial disease. ${ }^{[4]}$ So, proper control of BP in hypertensive patients is a must to prevent poor outcome in CKD patients. The utilisation pattern studies are components of prescription auditing in health sector that monitors prescribing practices and commends required modifications to achieve rational drug use.[5]

Hence, our study was designed keeping in mind that limited numbers of literatures accessible in prescribing 
various anti-hypertensives drug combinations to analyse current prescribing patterns in the management of CKD patients with hypertension and to suggest ways to rationalize drug use, minimise medication error and augment outcome therapeutically.

\section{MATERIAL AND METHODS}

A descriptive, prospective and hospital-based study was conducted in the Department of Nephrology in association with Department of Pharmacology in S.C.B. Medical College and Hospital, Cuttack, over a period of 6 months, i.e. $1^{\text {st } J a n . ~}$ 2015 to $30^{\text {th }}$ June 2015. After obtaining the clearance and approval from the Institutional Ethics Committee, 100 inpatients who gave informed consent were included in the study. The patients were diagnosed of having Chronic Kidney Disease by the consultant Nephrologist according to KDOQI guidelines. Clinical and biochemical parameters were collected at the time of admission and after 3 months.

\section{Inclusion Criteria}

Patients diagnosed as CKD stage (III-V) within the age group 18-78 having eGFR varies from $4-28 \mathrm{~mL} / \mathrm{min} / 1.73 \mathrm{~m}^{2}$ undergoing haemodialysis for the $1^{\text {st }}$ time were included in the study.

\section{Exclusion Criteria}

- Terminally ill patients co-infected with HIV or Hepatitis or with any infective conditions or with any autoimmune diseases or continuing medications for the same.

- $\quad$ Patients with any sort of cardiac ailments (i.e., Coronary Artery Disease, Angina, Heart Failure, Arrhythmia).

- $\quad$ Patients with renal transplant.

- Patients less than 18 yrs.

- Pregnant and lactating women.

- Surgical conditions like kidney stone, tumours and trauma.

Demographic, clinical and medication details were collected from patients' case sheets in a specially designed proforma.

\section{STATISTICS}

Descriptive statistics is done by measuring different proportions. Statistical measurements were done in SPSS version 21.0. Before and after analysis was done by paired-ttest. Graphical representation was done in using Microsoft Excel.

\section{RESULTS}

A total of 100 case records of patients having chronic kidney disease (Stage III, IV, V) and on anti-hypertensive medications were compiled and interpreted. CKD was more prevalent in males 69 (69\%) and 31 (31\%) females with male-to-female ratio of $2.7: 1$. Most of the patients (43\%) belonged to the age group of 51-60 years followed by (29\%) in age group 41-50 years. Among the anti-hypertensive agents, most frequently prescribed was Calcium Channel Blockers (32.47\%), in which Amlodipine was prescribed in 51 patients followed by Cilnidipine in 18 and Nifedipine in 07 patients. Second most frequently used anti-hypertensives were $\beta$ blockers (24.78\%) of which Metoprolol and Atenolol was prescribed in 44 and 13 patients respectively; Diuretics prescribed in $23.50 \%$ of case records included Torsemide,
Furosemide, Metolazone in 28, 15 and 12 patients respectively. Among the $\alpha$ blocker Prazosin was prescribed in 18 patients and centrally acting drugs like Clonidine was prescribed in 24 patients. Angiotensin Converting Enzyme Inhibitors like Enalapril was prescribed in 3 patients.

\section{DISCUSSIONS}

Almost one billion people (26\% approximately) of the adult population of the world are hypertensives.[6] Both developed (333 million) and underdeveloped (639 million) countries are affected.[7] The Kidney Disease Outcomes Quality Initiative (KDOQI) of the National Kidney Foundation defines CKD as either kidney damage and/or a decreased glomerular filtration rate of less than $60 \mathrm{~mL} / \mathrm{min} / 1.73 \mathrm{~m} 2$ for 3 months or more.[8] Hypertension (HTN) and CKD is cyclic in nature and has been found to occur in $85 \%$ to $95 \%$ of patients with CKD (stages III-V).[9] Hypertension increases the risk of various disorders like cardiovascular diseases including coronary arterial diseases, congestive heart failure, ischaemic and haemorrhagic stroke, renal failure and peripheral arterial disease. ${ }^{[4]}$ Elevated blood pressure causes about $54 \%$ of CVA and $47 \%$ of ischaemic heart disease worldwide.[10] Lowering of systolic blood pressure by 10-12 mmHg and diastolic blood pressure by 5-6 mmHg converse relative risk reduction of 35$40 \%$ for stroke and $12-16 \%$ for CHD within 5 years of the initiation of treatment. Risk of heart failure is also lowered by $>50 \%$. So, proper control of blood pressure in hypertensive patient is a must to prevent many of its complications. Treatment with anti-hypertensive agents reduces the incidence of all types of cerebrovascular accidents by $38 \%$ in women by $34 \%$ in men, by $36 \%$ in older persons and by $34 \%$ in persons older than 80 years.[11] Hence, one of the main objectives in CKD patients is to maintain blood pressure in the range recommended in different guidelines and to reduce the progression of renal disease and reduce cardiovascular morbidity and mortality.[12-14] To achieve and maintain adequate control on blood pressure, most of the patients with CKD require combinations of multiple anti-hypertensive agents.[15]

Out of the 100 prescriptions evaluated, males were predominant in the study population which is in agreement with the results of various other studies.[8] The (mean \pm SD) age of the patients was $55.37 \pm 13.41$ years with a range between 18 and 74 years. Average number of drugs per prescription was $9 \pm 2.28$ in the beginning of the study. The practice of polypharmacy is seen as in similar studies in CKD patients with average number of drugs per prescription varying from 8 to $12 .[16,17]$

\begin{tabular}{|c|c|}
\hline Characteristics & \\
\hline Mean Age (Years) & $55.37 \pm 13.41$ \\
\hline Gender & \\
\hline Male & $73(73 \%)$ \\
\hline Female & $27(27 \%)$ \\
\hline Stages of CKD eGFR (mL/min/1.73 m) ${ }^{2}$ & \\
\hline Stage v (<15) & $71(71 \%)$ \\
\hline Stage iv (15-29) & $24(24 \%)$ \\
\hline Stage iii (30-59) & $5(16 \%)$ \\
\hline Co-morbidities & $86(86 \%)$ \\
\hline Anaemia & $100(100 \%)$ \\
\hline Hypertension &
\end{tabular}




\begin{tabular}{|c|c|}
\hline U.T.I & $38(38 \%)$ \\
\hline Type II DM \pm Proteinuria & $42(42 \%)$ \\
\hline Glomerulonephritis & $8(8 \%)$ \\
\hline $\begin{array}{c}\text { Chronic Obstructive Pulmonary Disease, } \\
\text { Hypothyroidism, Metabolic Derangements }\end{array}$ & $5(5 \%)$ each \\
\hline \multicolumn{2}{|c|}{ Table 1: Demographic \& Clinical Characteristics } \\
\hline
\end{tabular}

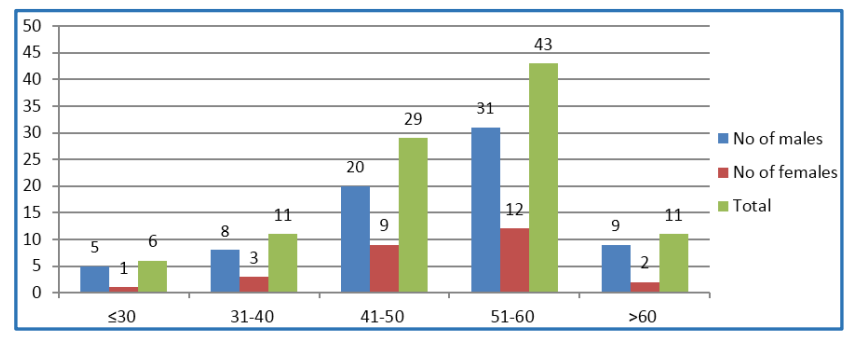

Fig. 1: Age Wise Distribution of Patients

\begin{tabular}{|c|c|c|c|c|c|}
\hline $\begin{array}{c}\text { Clinical } \\
\text { Parameters }\end{array}$ & $\begin{array}{c}\text { Mean } \pm \text { SD } \\
\text { (Beginning } \\
\text { of Study) }\end{array}$ & $\begin{array}{c}\text { Mean } \pm \text { SD } \\
\text { (After } 3 \\
\text { Months ) }\end{array}$ & T Value & $\begin{array}{c}\text { Confidence } \\
\text { Interval }\end{array}$ & $\begin{array}{c}\mathbf{P} \\
\text { Value }\end{array}$ \\
\hline $\begin{array}{c}\text { Haemoglobin } \\
(\mathrm{gm} / \mathrm{dL})\end{array}$ & $\begin{array}{c}8.595 \pm \\
2.171\end{array}$ & $10.451 \pm 1.538$ & -21.446 & $\begin{array}{c}-2.027 \text { to } \\
-1.684\end{array}$ & 0.000 \\
\hline $\begin{array}{c}\text { Systolic Blood } \\
\text { Pressure } \\
\text { (mmHg) }\end{array}$ & $\begin{array}{c}168.92 \pm \\
20.996\end{array}$ & $\begin{array}{c}145.82 \pm \\
13.994\end{array}$ & 11.872 & $\begin{array}{c}19.239 \text { to } \\
26.961\end{array}$ & 0.000 \\
\hline $\begin{array}{c}\text { Diastolic Blood } \\
\text { Pressure } \\
\text { (mmHg) }\end{array}$ & $\begin{array}{l}94.52 \pm \\
7.578\end{array}$ & $\begin{array}{c}89.44 \pm \\
6.458\end{array}$ & 6.791 & $\begin{array}{c}3.596 \text { to } \\
6.564\end{array}$ & 0.000 \\
\hline $\begin{array}{c}\text { Serum } \\
\text { Creatinine } \\
(\mathrm{mg} / \mathrm{dL})\end{array}$ & $\begin{array}{c}10.835 \pm \\
4.223\end{array}$ & $\begin{array}{c}7.639 \pm \\
3.771\end{array}$ & 29.232 & $\begin{array}{l}2.979 \text { to } \\
3.412\end{array}$ & 0.000 \\
\hline $\begin{array}{c}\text { Plasma Urea } \\
(\mathrm{mg} / \mathrm{dL})\end{array}$ & $\begin{array}{c}117.89 \pm \\
30.698\end{array}$ & $\begin{array}{l}90.36 \pm \\
29.772\end{array}$ & 30.072 & $\begin{array}{c}25.714 \text { to } \\
29.346\end{array}$ & 0.000 \\
\hline $\begin{array}{l}\text { Serum Sodium } \\
(\mathrm{mEq} / \mathrm{dL})\end{array}$ & $\begin{array}{c}136.04 \pm \\
4.127\end{array}$ & $\begin{array}{c}136.61 \pm \\
2.538\end{array}$ & -1.646 & $\begin{array}{c}-1.257 \text { to } \\
0.117\end{array}$ & 0.103 \\
\hline $\begin{array}{c}\text { Serum } \\
\text { Potassium } \\
(\mathrm{mEq} / \mathrm{dL})\end{array}$ & $\begin{array}{l}4.99 \pm \\
0.787\end{array}$ & $\begin{array}{l}4.63 \pm \\
0.553\end{array}$ & 9.326 & $\begin{array}{l}.285 \text { to } \\
.439\end{array}$ & 0.000 \\
\hline
\end{tabular}

\begin{tabular}{|c|c|}
\hline Prescriptions Analysed & 100 \\
\hline No. of different class of drugs prescribed & 49 \\
\hline $\begin{array}{l}\text { Average number of drugs per prescription in the } \\
\text { beginning of the study during dialysis and non- } \\
\text { dialysis days approx. }\end{array}$ & $9.49 \pm 1.43$ \\
\hline $\begin{array}{c}\text { Average number of drugs per prescription after } \\
6 \text { months of the study during dialysis and non- } \\
\text { dialysis days approx. }\end{array}$ & $6.92 \pm 1.10$ \\
\hline $\begin{array}{l}\text { No. of Anti-hypertensive agents } \\
\text { in EDL 2014, State Odisha }\end{array}$ & $\begin{array}{c}6 \text { out of } \\
11\end{array}$ \\
\hline No. of drugs prescribed by generic name & 00 \\
\hline
\end{tabular}

The target blood pressure in CKD patients should be maintained below 140/90 mmHg. High systolic pressure increases the myocardial work, while low diastolic pressure reduces myocardial circulation and increases the myocardial ischaemia leading to cardiovascular morbidity and mortality.[18] Calcium Channel Blockers (CCBs) were most frequently prescribed anti-hypertensive drugs in our study corroborate with the study of Bailie GR et al[5] followed by beta blockers (Metoprolol). Among the calcium channel blockers, Amlodipine followed by Cilnidipine and sustained release Nifedipine was most commonly prescribed and among the diuretics it is Torsemide. Cilnidipine though has its longer duration of action of 24 hours, also prevents reflex tachycardia as it selectively acts on both $\mathrm{L}$ and $\mathrm{N}$ type of calcium channels, still Amlodipine (L type of calcium channel blocker) was prescribed because of free supply by the Government of the State.

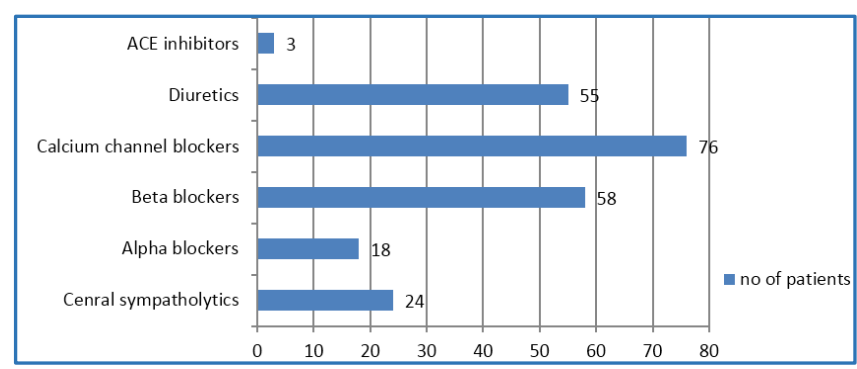

Fig. 2: Frequency of Anti-Hypertensive Agents Used

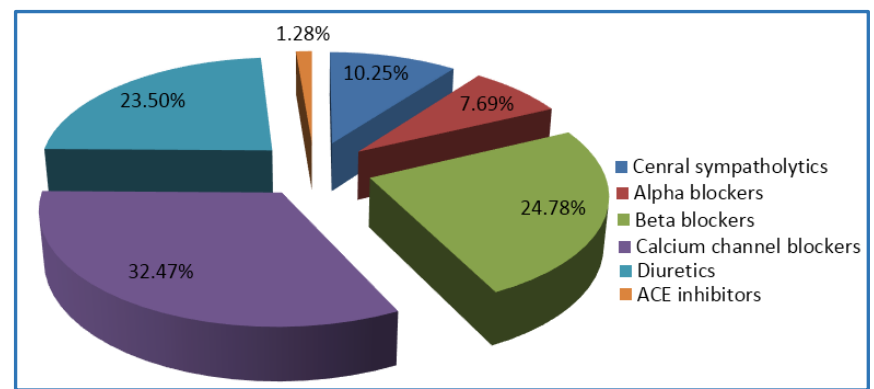

Fig. 3: Individual Classes of Anti-Hypertensive Agents among the Total Anti-Hypertensive Agents Prescribed in Patients of CKD

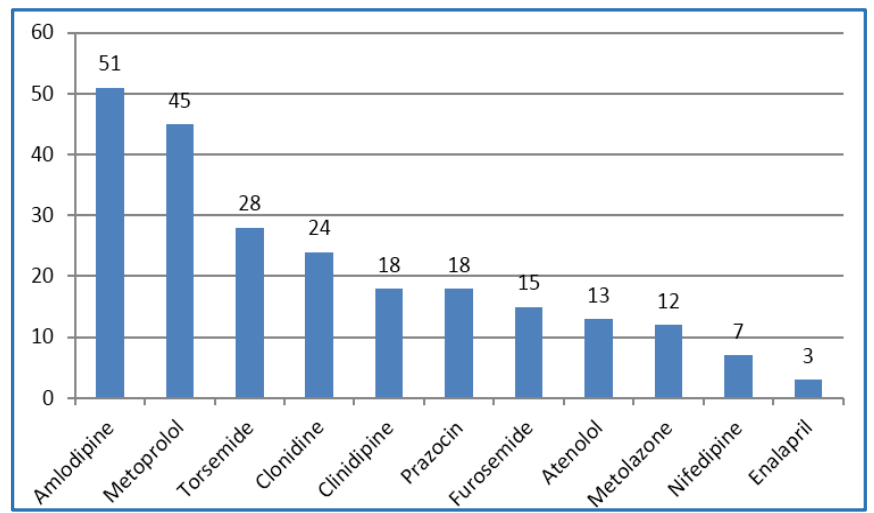

Fig. 4: Frequency of Individual Anti-Hypertensives Prescribed in Patients with CKD

Torsemide was preferred over furosemide due to its longer duration of action and increased potency. Beta blockers were less commonly used in diabetics than in nondiabetic with hypertension, because of its known adverse effects in diabetic patients with hypertension because of its negative effect on lipid profiles and hypoglycaemic unawareness. Use of anti-hypertensive drugs such as selective beta blocker, alpha-blocker, CCB and/or other combinations more commonly used in non-diabetic than in diabetics. Beta blocker is preferred in haemodialysis patients due to overactivity of renin-angiotensin-aldosterone system, 
increased levels of sympathetic activity in haemodialysis patients. Beta blockers have been suggested to be cardioprotective in haemodialysis patients.[19] But beta blockers are underutilized in type 2 diabetes mellitus cases because of some expected side effects.

In chronic kidney disease, hyperkalaemia is more likely to develop when Angiotensin Converting Enzyme (ACE) inhibitors or Angiotensin Receptor Blockers (ARBs) are prescribed. Unlike CCBs, most of the ACE inhibitors need dose modification in renal failure. Positive results were found primarily in patients with proteinuria, whereas the benefit was less substantial for those without proteinuria. That is the reason probably ACE inhibitors or ARBs were underutilized. One systemic review. ${ }^{[20]}$ showed that ACE inhibitors or ARBS are very fruitful in CKD grade 1-3 patients, which reduces the ESRD risk. Though most of the patients in our study are CKD stage 5, so prescribing ACE inhibitors and ARBs seems illogical.

Centrally acting Anti-Hypertensives lowers BP without compromising the renal blood flow or glomerular filtration rate. ${ }^{[8]}$ Sympathetic overactivity is commonly seen in chronic kidney disease and is an important contributor to increasing the risk of cardiovascular events as well as increasing renal disease progression. Many of these agents were orally administered, but in some patients diuretics were also administered by parenteral route.

\begin{tabular}{|c|c|c|c|c|}
\hline $\begin{array}{c}\text { Blood } \\
\text { Pressure }\end{array}$ & $\begin{array}{c}\text { No. of } \\
\text { Patients at } \\
\text { Time of } \\
\text { Admission }\end{array}$ & $\begin{array}{c}\% \\
\text { Tage }\end{array}$ & $\begin{array}{c}\text { No. of } \\
\text { Patients } \\
\text { after 3 } \\
\text { Months }\end{array}$ & $\begin{array}{c}\% \\
\text { Tage }\end{array}$ \\
\hline$<130 / 80$ & 0 & $0 \%$ & 11 & $11 \%$ \\
\hline $\begin{array}{c}<140 / 90- \\
130 / 80\end{array}$ & 5 & $5 \%$ & 23 & $23 \%$ \\
\hline $\begin{array}{c}<150 / 90- \\
140 / 90\end{array}$ & 19 & $19 \%$ & 39 & $39 \%$ \\
\hline$>150 / 90$ & 76 & $76 \%$ & 27 & $27 \%$ \\
\hline \multicolumn{4}{|c|}{ Table 4: Control of Blood Pressure in } \\
Patients Before and After 3 Months \\
\hline
\end{tabular}

The degree of control in blood pressure is shown in Table 1. Control of hypertension in CKD patients was difficult to bring under control. More than two-third of the patients $(66 \%)$ had BP $>140 / 90 \mathrm{mmHg}$. About one-third of the patients (34\%) had BP control <140/90 mmHg. Intensive BP control was present in around one-tenth of total patients (11\%). Despite more efforts with use of more antihypertensive agents $(2.34 \pm 0.81$ and $2.93 \pm 1.20$ vs $1.33 \pm 0.50)$ uncontrolled group had BP $>140 / 90 \mathrm{mmHg}$ in comparison to intensive control group with $\mathrm{BP}<130 / 80 \mathrm{mmHg}$.

Constancy to established target of blood pressure is low for participants with CKD in spite of growing evidence that control of hypertension can slow the decline in GFR, reduce proteinuria and reduce the incidence of cardiovascular complications in CKD.[21-25] Because the CKD population is characterized by wide pulse pressure and isolated systolic hypertension, more aggressive expeditions focusing on systolic hypertension in this population are necessary and the role of vascular stiffness in the treatment of hypertension in CKD should be evaluated.

\section{CONCLUSION}

Data of a total of 100 prescriptions pertaining to CKD patients were analysed. Anti-hypertensive agents have been employed with various permutations and combinations among the dialysis patients. The prevalence of CKD was higher in males. The preferential drugs employed among anti-hypertensives were calcium channel blockers, $\beta$ blockers, diuretics, centrally acting anti-hypertensives and ACE inhibitors. It provides a framework for continuous prescription audit in a hospitalbased setting and suggests possible improvement in prescription practices in patients suffering from chronic kidney disease.

\section{REFERENCES}

1. Shalini S, Ravichandran V, Mohanty BK, et al. Drug utilization studies- an overview. International Journal of Pharmaceutical Sciences and Nanotechnology 2010;3(1):803-10.

2. Levey AS, Eckardt KU, Tsukamoto Y. Definition and classification of chronic kidney disease: a position statement from kidney disease: improving global outcomes (KDIGO). Kidney Int 2005;67:2089-100.

3. Gooneratne IK, Ranaweera AKP, Liyanarachchi NP, et al. Epidemiology of chronic kidney disease in a Sri Lankan population. Int J Diabetes Dev Ctries 2008;28(2):60-4.

4. Kotchen TA. Hypertensive vascular disease. In Longo DL, Kasper DL, Jameson JL, et al. Harrison's Principles of Internal Medicine (18ed). New York: McGrawHill Medical 2012:2042-59.

5. Bailie GR, Eisele G, Liu L, et al. Patterns of medication use in the RRI-CKD study: focus on medication with cardiovascular effect. Nephrol Dial Transplant 2005;20(6):1110-5.

6. Bakris GL, Williams M, Dworkin L, et al. Preserving renal function in adults with hypertension and diabetes: a consensus approach. Amer J Kidney Dis 2000;36(3): 646-61.

7. Kearney PM, Whelton M, Reynolds K, et al. Global burden of hypertension: analysis of worldwide data. Lancet 2005;365(9455):217-23.

8. National kidney foundation. KDOQI clinical practice guidelines for chronic kidney disease: evaluation, classification, and stratification. Am J Kidney Dis 2002;39:S1-266.

9. Rao MV, Qiu Y, Wang C, et al. Hypertension and CKD: kidney early evaluation program and national health and nutrition examination survey, 1999-2004. Am J Kidney Dis 2008;51(4 suppl 2):S30-7.

10. Kaplan NM, Victor R. Hypertension in the population at large. In Kaplan NM, Victor RG (eds). Kaplan's clinical hypertension (10th ed). Philadelphia, Lippincott Williams \& Wilkins 2010:1-19.

11. Aronow WS, Frishman WH. Treatment of hypertension and prevention of ischaemic stroke. Current Cardiol Reports 2004;6(2):124-9.

12. Chobanian AV, Bakris GL, Black HR, et al. The seventh report of the joint national committee on prevention, detection, evaluation, and treatment of high blood pressure: the JNC 7 report. JAMA 2003;289(19):2560-72.

13. American diabetes association. Standards of medical care in diabetes-2012. Diabetes Care 2012;35(1):S11-63. 
14. Bakris GL, Williams M, Dworkin L, et al. Preserving renal function in adults with hypertension and diabetes: a consensus approach national kidney foundation hypertension and diabetes executive committees working group. Am J Kidney Dis 2000;36(3):646-61.

15. Remuzzi G, Chiurchiu C, Ruggenenti P. Proteinuria predicting outcome in renal disease: non-diabetic nephropathies (REIN). Kidney Int Suppl 2004;92:S90-6.

16. Manley HJ, Garvin CG, Drayer DK, et al. Medication prescription pattern in ambulatory haemodialysis patients: comparison of USRDS to a large not for profit dialysis provider. Nephrol Dial Transplant 2004;19(7):1842-8.

17. Junius-Walker $\mathrm{U}$, Theile G, Hummers-Pradier E. Prevalence and predictors of polypharmacy among older primary care patients in Germany. FAM Pract 2007;24(1):14-9.

18. Amaresan MS, Geetha R. Early diagnosis of CKD and its prevention. JAPI 2008;56:41-6.

19. Levin NW, Kotank P, Eckardt KU, et al. Blood pressure in chronic kidney disease stage 5D-report from a kidney disease: improving global outcomes controversies conference. Kidney International 2009;10:1-12.

20. Sharma P, Blackburn RC, Parke CL, et al. Angiotensin converting enzyme inhibitors and angiotensin receptor blockers for adults with early (stage 1 to 3 ) non-diabetic chronic kidney disease. Cochrane Database Syst Rev 2011;10:CD007751.
21. Shulman NB, Ford CE, Hall WD, et al. Prognostic value of serum creatinine and effect of treatment of hypertension on renal function results from the hypertension detection and follow-up program the hypertension detection and follow-up program cooperative group. Hypertension and Renal Function 1989;13(5):180-93.

22. Walker WG, Neaton JD, Cutler JA, et al. Renal function change in hypertensive members of the multiple risk factor intervention trial racial and treatment effects the MRFIT research group. J Am Med Assoc 1992;268(21):3085-91.

23. Peterson JC, Adler S, Burkart JM, et al. Blood pressure control, proteinuria, and the progression of renal disease. the modification of diet in renal disease study. Ann Intern Med 1995;123(10):754-62.

24. Wright JT, Bakris G, Greene T, et al. Effect of blood pressure lowering and anti-hypertensive drug class on progression of hypertensive kidney disease: results from the AASK trial. J Am Med Assoc 2002;288(19):2421-31.

25. Jafar TH, Stark PC, Schmid $\mathrm{CH}$, et al. Progression of chronic kidney disease: the role of blood pressure control, proteinuria, and angiotensin converting enzyme inhibition: a patient-level meta-analysis. Ann Intern Med 2003;139(4):244-52. 